Marquette University

e-Publications@Marquette

4-1-1997

\title{
An Unusual Stereochemical Outcome in the Oxidatively Induced Reductive Elimination of (Pentenediyl)iron Complexes
}

Young K. Yun

William Donaldson

Marquette University, william.donaldson@marquette.edu

Accepted version. Journal of the American Chemical Society, Volume 119, No. 17 (1997), DOI. (C) 1997 American Chemical Society. Used with permission. 


\title{
An Unusual Stereochemical Outcome in the Oxidatively Induced Reductive Elimination of (Pentenediyl)iron Complexes
}

\author{
Young K. Yun \\ Department of Chemistry, Marquette University, \\ Milwaukee, WI \\ William A. Donaldson \\ Department of Chemistry, Marquette University, \\ Milwaukee, WI
}

Oxidatively induced reductive elimination is an important reaction step in numerous stoichiometric and catalytic transition metal mediated carbon-carbon bond formations. This process is well-known to occur with retention of stereochemistry. ${ }^{1} \mathrm{We}^{2}$ and others ${ }^{3}$ have reported that the oxidative decomplexation of (pentenediyl)iron complexes bearing an electron-withdrawing substituent provides a novel methodology to generate vinylcyclopropanes. ${ }^{4}$ We herein report on an unexpected stereochemical outcome for certain substrates and propose a mechanism to account for these results. 
We have previously reported that the reaction of tricarbonyl(1(methoxycarbonyl)pentadienyl)iron(1+) cation with malonate anions occurs regioselectively at an internal position (C2) to give stable (pentenediyl)iron complexes $\mathbf{1 a}-\mathbf{c} .{ }^{6}$ The relative stereochemistry of $\mathbf{1 a}$ and $\mathbf{1 b}$ were established by X-ray diffraction analysis. ${ }^{6}$ Oxidative decomplexation of $\mathbf{1 a}$ with cerium ammonium nitrate (CAN, 10 equiv, DMF or $\mathrm{MeOH}$ ) generates the vinylcyclopropane $\mathbf{2} \mathbf{a}$ as the major product (Table 1 ; entry 1 ). This result is consistent with an oxidatively induced reductive elimination occuring with retention of stereochemistry. In comparison, oxidation of 1a with trimethylamine $\mathrm{N}$-oxide (TMANO, $\mathrm{C}_{6} \mathrm{H}_{6}$, reflux) gave a mixture of diastereomeric vinylcyclopropanes $\mathbf{2 a}, \mathbf{3 a}$, and $\mathbf{4 a}$ (Table 1 ; entry 2 ). The relative stereochemistries of $\mathbf{2} \mathbf{a}, \mathbf{3 a}$, and $\mathbf{4 a}$ are based on their ${ }^{1} \mathrm{H}$ NMR spectral data. ${ }^{7}$ In particular, the ring protons of each with a cis relationship are coupled by $\mathrm{ca} .9 \mathrm{~Hz}$, while ring protons with a trans relationship are coupled by ca. $5-6 \mathrm{~Hz} .{ }^{8}$ It is important to note that vinylcyclopropane $\mathbf{2 a}$ does not isomerize to $\mathbf{3} \mathbf{a}$ or $\mathbf{4 a}$ upon treatment with either TMANO or triethylamine $\left(\mathrm{C}_{6} \mathrm{H}_{6}, 80^{\circ} \mathrm{C}\right)$. Thus, the products $\mathbf{3} \mathbf{a}$ and $\mathbf{4 a}$ are not the result of rearrangement or epimerization of $\mathbf{2 a}$.

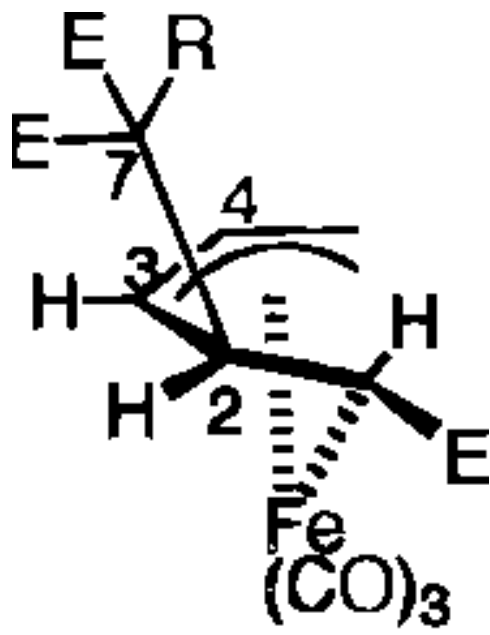

1

Journal of the American Chemical Society, Vol 119, No. 17 (1997): pg. 4084-4085. DOI. This article is (C) American Chemical Society and permission has been granted for this version to appear in e-Publications@Marquette. American Chemical Society does not grant permission for this article to be further copied/distributed or hosted elsewhere without the express permission from American Chemical Society. 
Table 1. Oxidative Decomplexation of (Pentenediyl)iron Complexes ( $\mathrm{E}=$ $\mathrm{CO}_{2} \mathrm{Me} ; \mathbf{a}, \mathrm{R}=\mathrm{H} ; \mathbf{b}, \mathrm{R}=\mathrm{Me} ; \mathbf{c}, \mathrm{R}=\mathrm{OMe}$ )

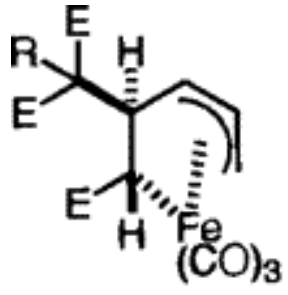

1

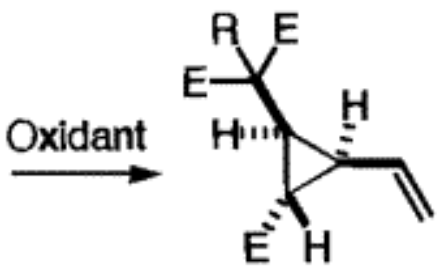

2

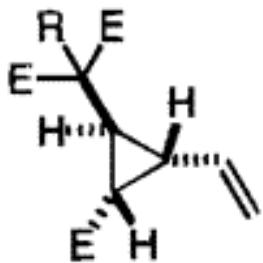

3

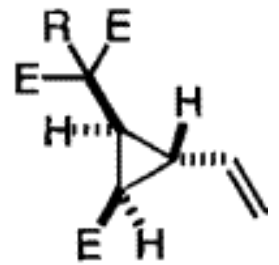

4

$\begin{array}{lllll}\text { entry } & \mathrm{R} & \text { conditions } & \text { product ratio }(\mathbf{2 : 3 : 4}) & \text { total yield (\%) } \\ 1 & \mathrm{H}(\mathbf{a}) & \mathrm{CAN} / \mathrm{DMF} / 23^{\circ} \mathrm{C} & 10: 1: 0 & 70 \\ 2 & \mathrm{H}(\mathbf{a}) & \mathrm{TMANO}^{\circ} \mathrm{C}_{6} \mathrm{H}_{6} / 80^{\circ} \mathrm{C} & 2: 4: 1 & 69 \\ 3 & \mathrm{Me}(\mathbf{b}) & \mathrm{CAN} / \mathrm{DMF} / 23^{\circ} \mathrm{C} & 0: 1: 0 & 55 \\ 4 & \mathrm{Me}(\mathbf{b}) & \mathrm{TMAO}^{\circ} \mathrm{C}_{6} \mathrm{H}_{6} / 80^{\circ} \mathrm{C} & 0: 1: 0 & 56 \\ 5 & \mathrm{OMe}(\mathbf{c}) & \mathrm{CAN} / \mathrm{DMF} / 23^{\circ} \mathrm{C} & 0: 1: 0 & 25\end{array}$

In sharp contrast, oxidative decomplexation of $\mathbf{1 b}$ with either CAN or TMANO gave only $\mathbf{3 b}$ (Table 1 ; entries 4 and 5 ). The relative stereochemistry of vinylcyclopropane $\mathbf{3 b}$ was tentatively assigned on the basis of its ${ }^{1} \mathrm{H}$ NMR spectral data. ${ }^{7}$ In particular, the vinylic methine proton of $\mathbf{3 b}$ appears at $\delta 6.14 \mathrm{ppm}$, while those of vinylcyclopropanes 2a, 3a, and 4a appear at $\delta 5.26,6.07$, and 5.13 ppm, respectively. This tentative assignment was subsequently confirmed by X-ray diffraction analysis ${ }^{9}$ of a crystalline derivative (5b) prepared in an unambiguous fashion (eq 1). Similarly, the oxidative decomplexation of 1c gave 3c (25\%) along with recovered starting material (25\%) (Table 1 ; entry 5 ). The structure of $\mathbf{3 c}$ was assigned by comparision of its ${ }^{1} \mathrm{H}$ NMR spectral data with that of $\mathbf{3 b}$. The vinylcyclopropanes $\mathbf{3} \mathbf{b}$ and $\mathbf{3 c}$ represent oxidatively induced reductive elimination of $\mathbf{1 b}$ and 1c with apparent inversion of configuration at C3.

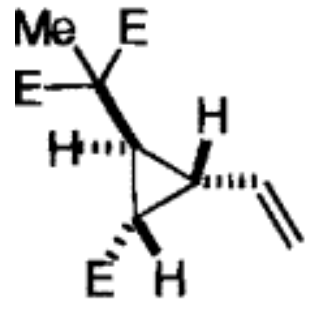

3b
1) $\mathrm{BH}_{3}: \mathrm{THF}$

2) $\mathrm{H}_{2} \mathrm{O}_{2} / \mathrm{KOH}$ 3) $\mathrm{PNBCl} / \mathrm{pyr}$

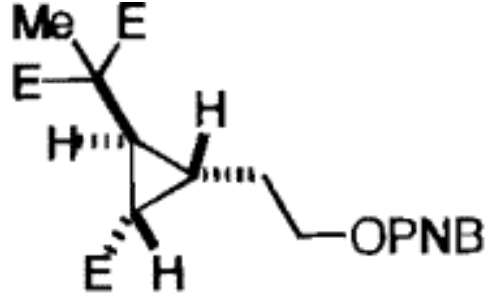

5b

Journal of the American Chemical Society, Vol 119, No. 17 (1997): pg. 4084-4085. DOI. This article is (C) American Chemical Society and permission has been granted for this version to appear in e-Publications@Marquette. American Chemical Society does not grant permission for this article to be further copied/distributed or hosted elsewhere without the express permission from American Chemical Society. 
The following mechanism is proposed to rationalize these results (Scheme 1). Oxidation of pentenediyl complex 1 leads directly to the species $\mathbf{6}$. A $\Pi-\sigma-\pi$ rearrangement of $\mathbf{6}$ via the metallocyclohexene intermediate $\mathbf{8}$ generates the species $\mathbf{7}$ with inversion of configuration at C3 (with respect to the configurations at C1 and C5). ${ }^{10}$ Reductive elimination of $\mathbf{6}$, with retention of configuration, leads to vinylcyclopropanes $\mathbf{2}$. For products $\mathbf{3}$, the apparent inversion of configuration results from $n-\sigma-n$ rearrangement followed by reductive elimination (i.e., inversion followed by retention). For $6 \mathbf{a}(\mathrm{R}=\mathrm{H})$ at 23 ${ }^{\circ} \mathrm{C}$, the $\Pi-\sigma-n$ rearrangement is slow with respect to reductive elimination; however, at higher reaction temperatures the rearrangement becomes rapid enough to allow for the formation of both $\mathbf{2} \mathbf{a}$ and $\mathbf{3} \mathbf{a}$. In comparison, rearrangement of $\mathbf{6} \mathbf{b}$ to $\mathbf{7} \mathbf{b}(\mathrm{R}=\mathrm{Me})$ is rapid compared to reductive elimination. It should be noted that the malonate substitutent occupies a pseudoaxial position and the $\mathrm{C} 1$ ester a pseudoequatorial position in $\mathbf{6}$ (cf., the X-ray crystal structures ${ }^{6}$ of

$\mathbf{1 a}$ and $\mathbf{1 b}$ ) while in $\mathbf{7}$ the malonate substitutent occupies a pseudoequatorial position and the $\mathrm{C} 1$ ester a pseudoaxial position. The equilibrium between $\mathbf{6} \mathbf{b}$ and $\mathbf{7 b}$ lies farther in the direction of $\mathbf{7 b}$ than does the equilibrium between $\mathbf{6 a}$ and $\mathbf{7 a}$, due to the greater steric bulk of the dimethyl methylmalonate substituent. ${ }^{10}$

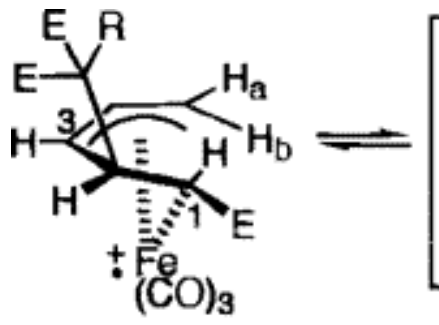

6 reductive elimination

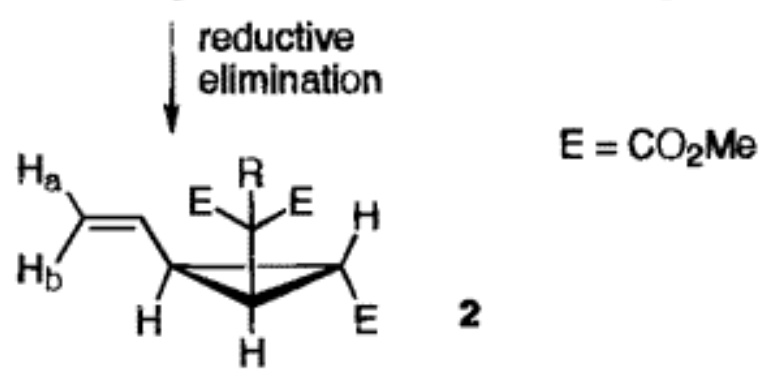

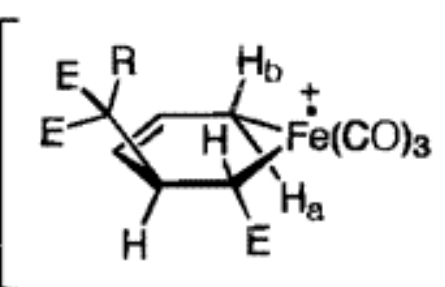

8

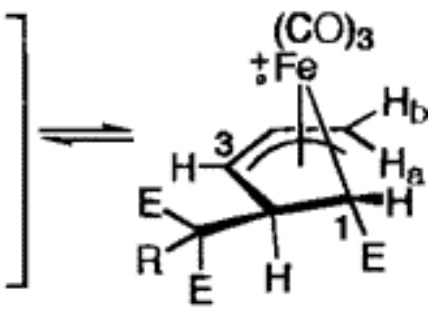

7

3

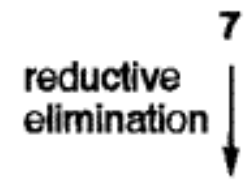

Scheme 1

Journal of the American Chemical Society, Vol 119, No. 17 (1997): pg. 4084-4085. DOI. This article is () American Chemical Society and permission has been granted for this version to appear in e-Publications@Marquette. American Chemical Society does not grant permission for this article to be further copied/distributed or hosted elsewhere without the express permission from American Chemical Society. 
It is proposed that the $n-\sigma-n$ rearrangement of the pentenediyl complexes occurs readily only for the oxidized species $\mathbf{6 / 7} .^{11}$ (Pentenediyl)iron complex $\mathbf{1 a}$ is recovered unchanged under the reaction conditions of entry 1 or 2 in the absence of oxidant (DMF/23 ${ }^{\circ} \mathrm{C} / 18 \mathrm{~h}$ or $\mathrm{C}_{6} \mathrm{H}_{6} / 80{ }^{\circ} \mathrm{C} / 4 \mathrm{~h}$ ), and $\mathbf{1 b}$ was recovered unchanged upon stirring to conditions in entry 3 in the absence of oxidant (DMF/18 $\mathrm{h} / 23^{\circ} \mathrm{C}$ ). If the 18 -electron pentenediyl complexes $\mathbf{1 a}$ or $\mathbf{1} \mathbf{b}$ undergo $\Pi-\sigma-\Pi$ rearrangement at these conditions, these equilibria must lie far in the direction of the $\mathbf{1} \mathbf{a}$ and $\mathbf{1} \mathbf{b}$, since no diastereomeric pentenediyl complexes are observed under the reaction conditions, in the absence of oxidant. Furthermore, when the oxidation of $\mathbf{1 a}$ (CAN/DMF/23 ${ }^{\circ} \mathrm{C}$ or TMANO $/ \mathrm{C}_{6} \mathrm{H}_{6} / 80{ }^{\circ} \mathrm{C}$ ) was carried to less than completion, the unreacted $\mathbf{1}$ a was recovered unchanged, in addition to the vinylcyclopropane products.

It may be noted that the $\Pi-\sigma-n$ rearrangement of $\mathbf{6}$ to 7 occurs with inversion of the exo-endo stereochemistry at the $\sigma$-bound end of the allylic portion of $\mathbf{6}$. If the proposed mechanism is valid, this inversion of stereochemistry should be reflected in the products. Toward this end, the deuterium-labeling studies were carried out. The stereoselectively deuterium-labeled cation $\mathbf{1 1}$ was prepared from $\mathbf{9}$ (Scheme 2) in a fashion similar to our previous preparation of the stereoselectively labeled cation $\mathbf{1 2} .{ }^{12}$ Cation 11, prepared by this method, was found to possess the deuterium label $75 \%$ in the exoposition and $25 \%$ in the endo-position, by integration of its ${ }^{1} \mathrm{H}$ NMR spectrum. Reaction of $\mathbf{1 1}$ with dimethyl malonate or dimethyl methylmalonate anion gave predominantly ${ }^{13}$ the pentenediyl complexes d-1a and d-1b in which deuterium was located $75 \%$ in the exo-position (Scheme 3).

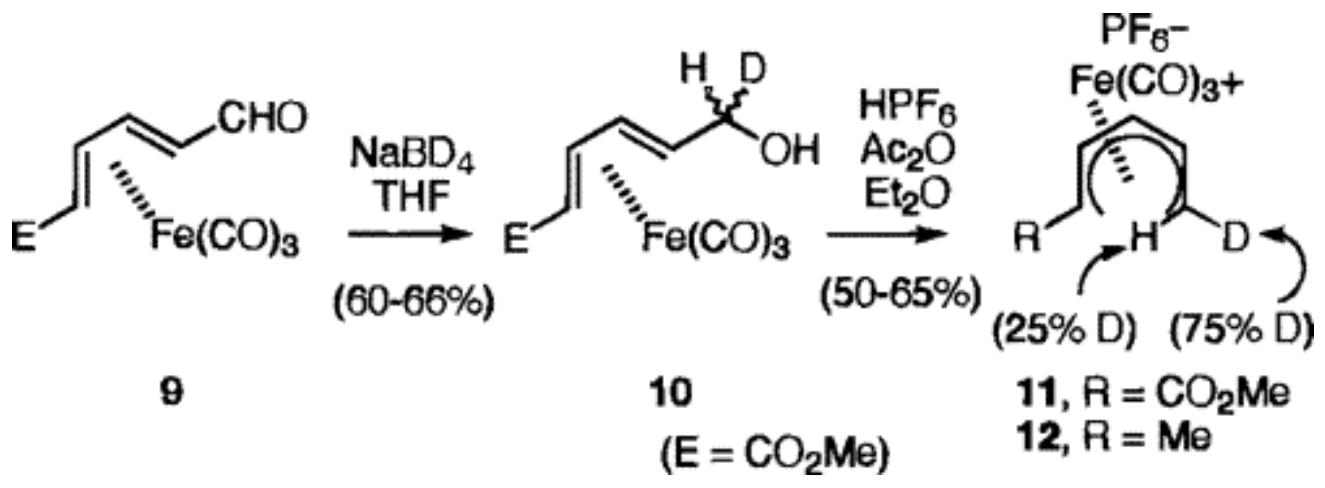

\section{Scheme 2}

Journal of the American Chemical Society, Vol 119, No. 17 (1997): pg. 4084-4085. DOI. This article is (C) American Chemical Society and permission has been granted for this version to appear in e-Publications@Marquette. American Chemical Society does not grant permission for this article to be further copied/distributed or hosted elsewhere without the express permission from American Chemical Society. 


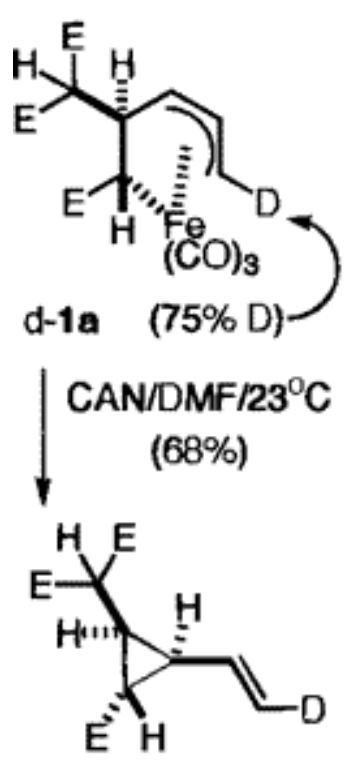

$\mathrm{d}-2 \mathrm{a}, 72 \% E$

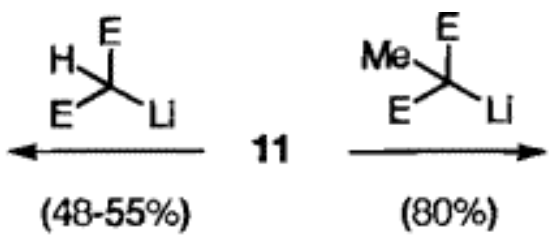

TMANO/ $\mathrm{C}_{6} \mathrm{H}_{6}$

$80^{\circ} \mathrm{C}$

$(83 \%)$

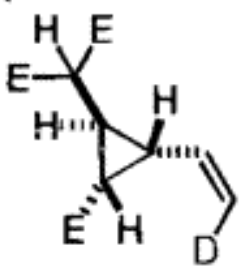

$$
\begin{gathered}
\text { d-3a, } 66 \% Z \\
\text { and } \\
\text { d-2a, } 71 \% E \\
\text { (d-2a:d-3a, 1:2) }
\end{gathered}
$$

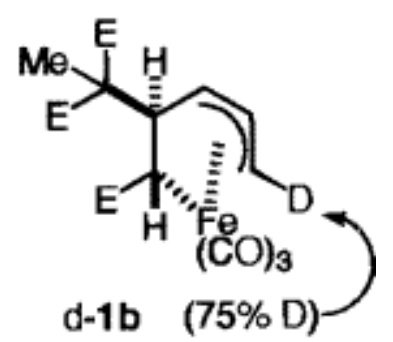

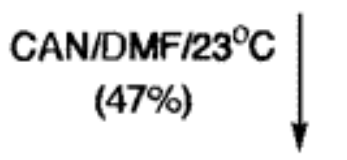<smiles>[2H]/C=C\[C@@H]1[C@H](C)[C@@H]1C(F)(F)F</smiles>

d-3b, $75 \%$ Z

$\left(\mathrm{E}=\mathrm{CO}_{2} \mathrm{Me}\right)$

\section{Scheme 3}

The oxidative decomplexation of $\mathrm{d}-\mathbf{1 a}$ (CAN/DMF/23 ${ }^{\circ} \mathrm{C}$ ) gave $\mathrm{d}$ 2a; ${ }^{1} \mathrm{H}$ NMR integration of the vinyl methylene protons indicated the product to be $72 \% E$ (Scheme 3 ). In comparison, oxidative decomplexation of $\mathbf{d - 1} \mathbf{1 b}\left(\mathrm{CAN} / \mathrm{DMF} / 23^{\circ} \mathrm{C}\right)$ gave $\mathbf{d - 3} \mathbf{3 b} ;{ }^{1} \mathrm{H}$ NMR integration of the vinyl methylene protons indicated the product to be $75 \% Z$ (Scheme 3). Finally, the oxidative decomplexation of d-1a (TMANO/ ${ }_{6} \mathrm{H}_{6} / 80{ }^{\circ} \mathrm{C}$ ) gave a mixture of $\mathbf{d - 2} \mathbf{a}$ and $\mathrm{d}-\mathbf{3 a}(1: 2)$. Analysis of the mixture indicated that $d-2 a$ was $71 \% E$ while $d-3 a$ was $66 \% Z$. Thus, inversion of configuration at the vinylcyclopropyl carbon is accompanied by an inversion in the stereochemistry about the $\mathrm{C}=\mathrm{C}$ double bond. These results are consistent with the mechanism proposed in Scheme 1.

We are currently examining the application of this methodology for the preparation of cyclopropyl-containing natural products. 
NOT THE PUBLISHED VERSION; this is the author's final, peer-reviewed manuscript. The published version may be accessed by following the link in the citation at the bottom of the page.

\section{Acknowledgment}

Financial support for this work was provided by the National Institutes of Health (GM-42641). High-resolution mass-spectral determinations were made at the Nebraska Center for Mass Spectrometry. The authors thank Mr. Victor G. Young, Jr. (University of Minnesota) for obtaining the X-ray crystal structure of $\mathbf{5 b}$ and Dr. Alain Krief (Universitaires Notre-Dame de la Paix, Belgium) for helpful discussions.

\section{Supporting Information Available}

Experimental details and spectroscopic data (7 pages). See any current masthead page for ordering and Internet access instructions.

\section{References}

${ }^{1}$ Collman, J. P.; Hegedus, L. S.; Norton, J. R.; Finke, R. G. Principle and Application of Organotransition metal Chemistry; University Science Books: Mill Valley, CA, 1987.

2Donaldson, W. A.; Ramaswamy, M. Tetrahedron Lett. 1989, 30, 1339-42.

3Saber, S. P.; Slawin, A. M.; Thomas, S. E.; Williams, D. J.; Ward, M. F.; Worthington, P. A. J. Chem. Soc., Chem. Commun. 1994, 2169-70. Jandeleit, B. Ph.D. Dissertation, Rheinisch-Westfälischen Technischen Hochschule Aachen, Germany, 1995.

${ }^{4}$ The reverse process, formation of (pentenediyl) $\mathrm{Fe}(\mathrm{CO})_{3}$ complexes from the reaction of vinylcyclopropanes with $\mathrm{Fe}(\mathrm{CO})_{5}$, has been reported. ${ }^{5}$ However, since the iron species generated as a byproduct in the present case is not $\mathrm{Fe}(\mathrm{CO})_{5}$, it can not be assumed that these reactions follow the same reversible reaction pathway.

${ }^{5}$ Aumann, R. J. Am. Chem. Soc. 1974, 96, 2631-2. Schulze, M. M.; Gockel, U. Tetrahedron Lett. 1996, 37, 357-8. Schulze, M. M.; Gockel, U. J. Organomet. Chem. 1996, 525, 155-8.

${ }^{6}$ Donaldson, W. A.; Shang, L.; Tao, C.; Yun, Y. K.; Ramaswamy, M.; Young, V. G. J. Organomet. Chem. 1997, in press.

${ }^{7}$ Selected $300 \mathrm{MHz}{ }^{1} \mathrm{H}$ NMR spectral data $\left(\mathrm{C}_{6} \mathrm{D}_{6}\right)$. For $2 \mathbf{a}$ : $\delta_{\mathrm{H}} 5.26$ (ddd, $\mathrm{J}=$ 7.5, 9.9, $17.1 \mathrm{~Hz}, 1 \mathrm{H}), 4.93(\mathrm{~d}, J=17.1 \mathrm{~Hz}, 1 \mathrm{H}), 4.88(\mathrm{~d}, J=11.4$ $\mathrm{Hz}, 1 \mathrm{H}), 3.27,3.26$, and $3.25(3 \mathrm{~s}, 9 \mathrm{H}), 3.04(\mathrm{~d}, J=11.0 \mathrm{~Hz}, 1 \mathrm{H})$, 2.57 (ddd, $J=4.9,9.6,11.1 \mathrm{~Hz}, 1 \mathrm{H}), 2.33(\mathrm{dt}, J=4.9,8.5 \mathrm{~Hz}, 1 \mathrm{H})$, 1.76 (apparent $t, J=4.9 \mathrm{~Hz}, 1 \mathrm{H}$ ). For $3 \mathrm{a}$ : $\delta_{\mathrm{H}} 6.07$ (ddd, $J=9.2,10.2$, $17.2 \mathrm{~Hz}, 1 \mathrm{H}), 5.16(\mathrm{dd}, J=1.2,17.1 \mathrm{~Hz}, 1 \mathrm{H}), 4.99(\mathrm{dd}, J=1.2,10.2$ $\mathrm{Hz}, 1 \mathrm{H}), 3.26,3.22$, and $3.21(3 \mathrm{~s}, 9 \mathrm{H}), 2.73(\mathrm{~d}, J=9.8 \mathrm{~Hz}, 1 \mathrm{H}), 2.53$ (ddd, $J=5.4,6.1,9.8 \mathrm{~Hz}, 1 \mathrm{H}), 1.88(\mathrm{dd}, J=5.3,9.1 \mathrm{~Hz}, 1 \mathrm{H}), 1.71$ $\left(\mathrm{dt}, J=6.2,9.1 \mathrm{~Hz}, 1 \mathrm{H}\right.$ ). For $4 \mathrm{a}: \delta_{\mathrm{H}} 5.13$ (ddd, $J=7.6,10.0,17.3$ $\mathrm{Hz}, 1 \mathrm{H}), 4.97(\mathrm{dd}, J=1.7,17.3 \mathrm{~Hz}, 1 \mathrm{H}), 4.80(\mathrm{dd}, J=1.7,10.0 \mathrm{~Hz}$, 
$1 \mathrm{H}), 4.23(\mathrm{~d}, J=10.7 \mathrm{~Hz}, 1 \mathrm{H}), 3.30,3.25$, and $3.23(3 \mathrm{~s}, 9 \mathrm{H}), 2.18$ (br q, $J=6.3 \mathrm{~Hz}, 1 \mathrm{H}$ ), 1.99 (ddd, $J=6.3,8.8,10.8 \mathrm{~Hz}, 1 \mathrm{H}$ ), 1.82 (dd, $J=5.0,8.9 \mathrm{~Hz}, 1 \mathrm{H})$. For $3 \mathbf{b}: \delta_{H} 6.14(\mathrm{ddd}, J=8.8,10.2,17.1 \mathrm{~Hz}$, $1 \mathrm{H}), 5.18(\mathrm{dd}, J=1.8,17.1 \mathrm{~Hz}, 1 \mathrm{H}), 5.02(\mathrm{dd}, J=1.8,10.2 \mathrm{~Hz}, 1 \mathrm{H})$, $3.31,3.22$, and $3.21(3 \mathrm{~s}, 9 \mathrm{H}), 2.61(\mathrm{dd}, J=5.9,6.6 \mathrm{~Hz}, 1 \mathrm{H}), 2.18$ $(\mathrm{dd}, J=5.9,9.3 \mathrm{~Hz}, 1 \mathrm{H}), 2.00(\mathrm{dt}, J=6.7,9.0 \mathrm{~Hz}, 1 \mathrm{H}), 1.23(\mathrm{~s}, 3 \mathrm{H})$.

${ }^{8}$ Silverstein, R. M.; Bassler, G. C.; Morrill, T. C. Spectrometric Identification of Organic Compounds; John Wiley \& Sons, Inc.: New York, 1991.

${ }^{9}$ Young, V. G., Jr.; Yun, Y. K.; Donaldson, W. A. Submitted.

${ }^{10}$ The difference in the steric sizes of the dimethyl malonate substituent present in 1a and the dimethyl methylmalonate substituent present in $\mathbf{1 b}$ is manifested in a considerably larger $\mathrm{C} 4-\mathrm{C} 3-\mathrm{C} 2-\mathrm{C} 7$ torsional angle for $\mathbf{1 b}\left(81.3^{\circ}\right)$ compared to $\mathbf{1 a}\left(65.3^{\circ}\right)$ in the crystal state. ${ }^{6}$

${ }^{11}$ Notably, syn-anti isomerization of (n-allyl)Fe(CO) $4^{+}$cations (18-electron complexes) via a $\Pi-\sigma-\Pi$ mechanism requires heating $\left(60^{\circ} \mathrm{C}\right)$ for extended periods of time (36-144 h). Gibson, D. H.; Erwin, D. K. J. Organomet. Chem. 1975, 86, C31-C33. Salzer, A.; Hafner, A. Helv. Chim. Acta 1983, 66, 1774-85.

${ }^{12}$ Donaldson, W. A.; Shang, L.; Ramaswamy, M.; Droste, C. A.; Tao, C.; Bennett, D. W. Organometallics 1995, 14, 5119-26.

${ }^{13}$ The reaction of lithium dimethyl malonate with (1(methoxycarbonyl)pentadienyl) $\mathrm{Fe}(\mathrm{CO}) 3_{3}{ }^{+}$gave $\mathbf{1 a}$ and a minor amount of diene complex $i(20: 1) .{ }^{4}$ The reaction of $\mathbf{1 1}$ with lithium dimethyl malonate gave d-1a and d-ia(6:1), while reaction of $\mathbf{1 1}$ with lithium dimethyl methylmalonate gave $\mathbf{d - 1} \mathbf{b}$ and $\mathbf{d - i b}(8: 1)$. This increase in the ratio of attack at C5 vs C2 is attributed to an inverse a-secondary isotope effect. 